Revista Eletrônica de Ciência Política, vol. 5, n. 2, 2014.

\title{
THE IMPACT OF GLOBALIZATION ON HUMAN DEVELOPMENT IN THE DEVELOPING COUNTRIES: THE CASE OF CENTRAL AND SOUTH AMERICA ${ }^{1}$
}

\author{
Ana Magdalena Figueroa ${ }^{2}$
}

\begin{abstract}
This research aims to empirically test the impact of globalization on human development by studying 17 Latin American countries in a range of time from 1995 to 2009, in order to confirm the hypothesis that the effect of globalization on human development of developing countries depends on specific aspects of globalization and human development, as well as the level of state fragility and delinquency. The motivation leading this research is the fact that globalization has not brought improvement in the developmental conditions of the population as a whole. The potential and originality of this study includes the contribution to providing evidence by testing empirically the relationship between globalization and human development in Central and South America in such a way that will allow us to differentiate what kind of globalization is positive or negative in distinct areas of human development. And this is with the purpose of helping policymakers to have a clearer idea of what can be done according to each country's peculiarities to enhance the human development in a globalized era. The outcomes from empirical data analysis that employ Panel Corrected Standard Errors (PCSE) modeling reveal that globalization has a conditional correlation with human development in Central and South American countries. That is, globalization has both positive and negative effects depending on specific aspects and their indicators to measure each aspect of globalization (economic, social or political globalization), the specific area of human development examined and the level of state fragility and delinquency in each country. The overall globalization index is found to have a positive effect on human development index. However, when globalization is disaggregated, the economic globalization sub index is found to have a negative effect, while social and political globalization sub indexes have positive effects on the human development in Central and South American countries.
\end{abstract}

Keywords: Human Development, Globalization, State Fragility, Delinquency.

\section{Resumo}

Esta pesquisa tem como objetivo testar empiricamente o impacto da globalização sobre o desenvolvimento humano por meio do estudo de 17 países latino-americanos em um intervalo de tempo de 1995 a 2009, a fim de confirmar a hipótese de que o efeito da globalização no desenvolvimento humano dos países em desenvolvimento depende de aspectos específicos da globalização e do desenvolvimento humano, bem como o nível de fragilidade do Estado e da delinquência. A motivação desta pesquisa é o fato de que a globalização não trouxe melhoria das condições de desenvolvimento da população como um todo. $O$ potencial e originalidade deste estudo inclui a contribuição para o fornecimento de provas, testando empiricamente a relação entre globalização e desenvolvimento humano na América Central e do Sul, de tal forma que nos permitirá diferenciar que tipo de globalização é positivo ou negativo em áreas distintas de desenvolvimento humano. Faz-se isso com o propósito de ajudar os decisores políticos a ter uma idéia mais clara do que pode ser feito de acordo com as peculiaridades de cada país para melhorar o desenvolvimento humano em uma era globalizada. Os resultados da análise dos dados empíricos que empregam modelagem de painel de erros padrão corrigidos (PCSE) revelam que a globalização tem uma correlação condicional com o desenvolvimento humano nos países da América central e sul-america. Ou seja, a globalização tem efeitos positivos e negativos, dependendo de aspectos específicos e seus indicadores para medir cada aspecto da globalização (mundialização econômica, social ou política), a área específica de desenvolvimento humano examinados e o nível de fragilidade do Estado e da delinquência em cada país. O índice geral de globalização tem um efeito positivo no índice de desenvolvimento humano. No entanto, quando a globalização é desagregada,

\footnotetext{
${ }^{1}$ DOI: http://dx.doi.org/10.5380/recp.v5i2.37371

2 Master's Degree in Political Science and International Relations, Chosun University, South Korea, 2012. Studying a PhD in International Relations, Universidade de São Paulo, Instituto de Relações Internacionais, since 2014.
} 
o sub-índice de globalização econômica tem um efeito negativo, enquanto os sub-índices sociais e políticos têm efeitos positivos sobre o desenvolvimento humano nos países da América do Sul e Central.

Palavras-chave: Desenvolvimento Humano, Globalização, Estado Fragilidade, delinquência.

\section{Resumen}

Esta investigación tiene como objetivo examinar empíricamente el impacto de la globalización en el Desarrollo Humano mediante el estudio de 17 países de América Latina durante un periodo de tiempo desde 1995 hasta 2009, con el fin de confirmar la hipótesis de que el efecto de la globalización en el Desarrollo Humano de los países en desarrollo depende de aspectos específicos de la globalización y del desarrollo humano mismo, así como del nivel de la fragilidad del Estado y de la delincuencia. La motivación que lleva esta investigación es el hecho de que la globalización no ha traído mejoras en las condiciones de desarrollo de la población total. El potencial y la originalidad de este estudio incluyen la contribución de proporcionar evidencia examinando empíricamente la relación entre globalización y desarrollo humano en América Central y América del Sur de una manera tal que nos permita diferenciar qué tipo de globalización es positiva o negativa en las diferentes áreas del Desarrollo Humano. Y esto es con el propósito de ayudar a los responsables de las políticas públicas para tener una idea más clara de lo que puede hacerse de acuerdo con las peculiaridades de cada país para mejorar el Desarrollo Humano en una era globalizada. Los resultados del análisis de los datos empíricos que emplean panel corrected standard errors (PCSE), revelan que la globalización tiene una correlación condicional con el Desarrollo Humano en países de Centro y Sur América. Es decir, la globalización tiene efectos positivos y negativos en función de aspectos específicos y sus indicadores para medir cada aspecto de la globalización (globalización económica, social o política), el área específica de Desarrollo Humano y el nivel de la fragilidad del Estado y de la delincuencia en cada país. Se encontró que el índice general de globalización tiene un efecto positivo en el Índice de Desarrollo Humano. Sin embargo, cuando la globalización es desagregada, el subíndice Globalización Económica tiene un efecto negativo, mientras que los subíndices Globalización Social y Política tienen efectos positivos sobre el Desarrollo Humano en países de Centro y Sur América.

Palabras clave: Desarrollo Humano, Globalización, Fragilidad del Estado, Delincuencia.

\section{INTRODUCTION}

The globalization process has not brought improvement in the developmental conditions of the population as a whole. The inquiries are why does not globalization affect positively to everybody? Does globalization strengthen or weaken the human development in the developing countries? When addressing these inquiries, while some studies reveal positive effects, others reveal negative effects on human development (UNDP 1999, 2000), but why is that?

It is important to address these inquiries to understand in detail what a country's advantages or disadvantages are when facing globalization. This will help policymakers to create wise policies according to each country's particular situation so that they can successfully integrate their economies to the international economic system and improve the human development at the same time. In the case of Latin America, it is structural violence and inequality that undermine economic and human development itself. There are 
also problems such as high levels of political and economic instability, urban violence, citizen insecurity, transnational drug trade and transnational criminal networks. In addition, it has been claimed that globalization makes weak states weaker because it diminishes the role of the state in the economy and the provision of welfare, giving a free pass to transnational corporations, which are occasionally more powerful than the state itself (Sorensen 2000). But, is this true?

The potential of this study includes the contribution to providing evidence by testing empirically the relationship between globalization and human development in Central and South America in such a way that will allow us to differentiate what kind of globalization is positive or negative in distinct areas of human development. And this is with the purpose of helping policymakers to have a clearer idea of what can be done according to each country's peculiarities to enhance the human development in a globalized era.

\section{LITERATURE REVIEW}

Scholars have addressed globalization from many different points of view and as a result, there is no such thing as a unique concept of globalization. Many scholars since very past times have tried to relate the concept of globalization to various theoretical issues and ideas such as modernization (Modelski 1972; Morse 1976), economic interdependence (Cooper 1968), global village (McLuhan 1964), and world society (Burton 1972). More recently, some scholars have argued that globalization is essentially an economic process and therefore it can be measured by trade and FDI (Ellwood 2001; Beer and Bosweel 2001; $\mathrm{Li}$ and Reuveny 2003). Other scholars also see globalization as a process affecting not only the economic realm, but also the social, cultural, political and even military realms (Baylis et al 2008; Dreher 2006).

To measure globalization is not easy because its many scopes are strongly related with one another and including them all in a model presents collinearity problems, but if one scope is missing from the model it also presents serious bias. Because of this situation, this study will understand globalization as a multidimensional concept based on Dreher's globalization index, which is the result of the combination of 23 variables into three subindexes: economic, social and political, and these three sub-indexes are in turn aggregated into an overall globalization index (Dreher, 2006). This index was created under the premise that globalization is a process that "erodes national boundaries, integrates national economies, cultures, technologies, and produces complex relations of mutual interdependence" (Dreher, 2006; Norris, 2000: 4). 
In this sense, economic globalization is understood by Dreher as the flow of goods, capital and services as well as information and perceptions that accompany market exchanges, while social globalization is understood as data on personal contacts, information flows, and cultural proximity, and employed these indicators into the social globalization sub-index as they are considered "the most pervasive form of globalism" according to Keohane and Nye (Keohane and Nye, apud Dreher, 2000: 4). In other words, the social globalization sub-index is a combination of sub-indicators such as telephone traffic, international tourism, foreign population, internet access and users, as well as access to television, radios and newspapers, and number of McDonalds restaurants. Lastly, political globalization will be understood as the diffusion of governmental policies through embassies abroad, membership in international organizations, and international treaties, as proposed by Kearney ${ }^{3}$, as these are aspects that reveal how open and integrated a country is in the international sphere. In short, this study intends to measure how all these dimensions of globalization impact the human development of the Latin American countries chosen for this analysis.

Human development is also a multidimensional concept. According to Amartya Sen, Nobel Prize laureate for economics in 1998, Human Development means to increase the richness of human life rather than the wealth of the economy ${ }^{4}$. The UNDP provides us with a concept of human development as “the process of enlarging people's choices and improving human capabilities (the range of things that they can do or be in life) and freedoms so they can live a long and healthy life, access to education and a decent standard of living, participate in their community and the decisions that affect their lives" (UNDP Reports 1992) ${ }^{5}$.

On the basis of these previous studies that define the concepts of globalization and human development, this study understands them as follows. Globalization will be understood as a multidimensional process by which different countries become more closely integrated in an economic, social, and political manner allowing an intensive flow of goods, services, money, people, ideas and cultures. On the other hand, human development will be understood as a multidimensional people-centered approach where the main concern is the improving of individual opportunities of having a better education, a healthier life and a better standard of living.

Scholars have previously addressed the relationship between globalization and human

3 ATKearney. (2002). Foreign Policy Index. Foreign Policy Magazine

4 UNDP, "Origins of the Human Development Approach" pp1

${ }^{5}$ UNDP Report - Belize 2011 pp1. 
development from different points of view coming to three main theories. The first theory is from the neoliberal school which understands globalization in terms of inflows and outflows of goods, services, capital, technology, and workers, and human development in terms of human well-being or a better quality of life (QOL - in terms of economic, consumer, social, and health well being). This school claims that trade, cross-border investment and technological innovation improve the efficiency of production and therefore it generates prosperity. This school also posits that benefits of globalization can be spread over all the people as long as the labor market is quick to respond to changes in supply and demand, and in that way improve the well-being of the population (Grennes 2003).

The second theory sees globalization as a new hegemonic plan or a new world order that transnational money and global powers operate in order to facilitate capital accumulation in the unrestricted market having as a result few improvements for most countries (Ming-Chang 2006; Petras and Veltmeyer 2001). Globalization pursues the private interests regardless of people (Smart 2003), which results in the inequality of benefits of those who are already less privileged, undermining the well-being of the populations (Scholte 2000). The third position recognizes that globalization is a process that has benefits and disadvantages as well (Sirgy 2004; Ming-Chang 2006; Mayer-Foulkes, 2006). Following this third position, this study hypothesizes that globalization has both, positive and negative effects on human development and it intends to explain, from a multidimensional point of view of both concepts, how and why these effects occur. Following this logic, the positive and negative effects of globalization on human development will be analyzed separately in an attempt to analyze those effects in a more disaggregated way.

\section{HYPOTHESES}

The main hypotheses are defined as follows:

1. The effect of globalization on the level of human development is specific to the various dimensions of globalization and human development.

2. The effect of globalization on the level of buman development depends on the level of state fragility and delinquency in Central and South American countries.

With respect to hypothesis 1 , previous empirical studies on globalization have proven that the reconciliation of their results is not possible. While some find positive correlations, others find negative, and others find both. There might be various reasons for this issue. 
The first reason might be related to the measure of globalization and human development used for the test. For example, in studying the effect of globalization and inequality, scholars found that the sign and significance of the effect of globalization on inequality depends on the measure of globalization used. They found that the effect is usually negative for trade/GDP while FDI/GDP is positive (White and Anderson 2001; Garret 2001). The second reason might be related to the sample selected. The impact of globalization will not be the same in industrialized countries and developing countries (Ming-Chang 2006). A third reason might be related to the local and regional characteristics taken or not taken into consideration at the time of the analysis.

With respect to hypothesis 2, state fragility is dangerous for national, regional and international stability, because they can be secure shelter for criminal organizations, focal points for drugs and arms trade, they can spread conflict and instability across their boarders and they can provide neither the essential public goods nor security for their populations (Ottaway and Mair 2004). The generality indicates that those countries with higher human development also have the lowest fragility index and delinquency. Based on the above central hypotheses, we can specify them as more testable hypotheses as follows:

1) The economic globalization process is likely to affect adversely the GDP per capita, life expectancy and public spending on education of developing countries in Central and South America when the environment characterized by state fragility and violence.

2) The social globalization process is likely to affect positively the GDP per capita, life expectancy and pubic investment on education of developing countries in Central and South America even under an environment characterized by state fragility and violence.

3) The political globalization process is likely to affect positively the GDP per capita and life expectancy of developing countries; but it is likely to affect negatively the public spending on education in Central and South America when th environment characterized by state fragility and violence.

\section{DATA AND METHODOLOGY}

The selected data in this research cover a period from 1995 to $2009^{6}$, which was the period in which the climax of economic and financial liberalization was felt in Latin America. 17 Latin American countries were selected for this research: Costa Rica, El Salvador, Guatemala, Honduras, Nicaragua, Panama, Argentina, Bolivia, Brazil, Chile, Colombia, Ecuador, Guyana, Paraguay, Peru, Uruguay and Venezuela.

\footnotetext{
${ }^{6}$ The data have been collected from different sources including the World Bank, Polity IV, Wikipedia, and each country's sources such as Police Reports of crime and homicides.
} 
The dependent variables are Human Development Index and its sub-indexes as proposed by the $\mathrm{UNDP}^{7}$ : Long Healthy Life (measured by life expectancy at birth), Knowledge (measured by the public spending on education) and a Decent Standard of Life (measured by GDP per capita). The independent variables are the Globalization proxies proposed by Dreher (2006), which are Economic Globalization, Social Globalization, Political Globalization and overall Globalization Index. Also trade and FDI will be used to account for consistency of the results. The control variables are Fragility Index, Delinquency, Democracy, and Government Effectiveness, country and time dummies in order to control for country characteristics and yearly shocks. The number of observations (country-year) in the full model is 255 . The number of observations or countries is 17 . The variables are described as follows:

Human Development: Our dependent variable and the subject of this study is human development and for its measure the Human Development Index will be used. The data has been collected from the UNDP Reports concerning the years 1995 to $2009^{8}$ for the 17 Central and South American countries stated above. The HDI measures the average achievements in a country in three basic dimensions of human development: a) A long and healthy life, as measured by the life expectancy at birth ${ }^{9}$; b) knowledge, as measured by the adult literacy rate (with two-thirds weight) and the combined primary, secondary and tertiary gross enrollment ratio (with one-third weight); and c) a decent standard of living, as measured by the Gross Domestic Product per capita (Purchasing Parity Power in \$US).

Globalization: The measure of globalization for this study as independent variable will follow 4 different methodologies in order to ensure the consistency of the results:

1. Trade and FDI have been widely used as a measure of globalization. Trade is calculated as imports+exports/GDP. FDI is calculated as the net inflows of investment from foreign investors. The data has been collected from the World Bank database $2010^{10}$.

2. KOF Globalization Index is based on Axel Dreher's work 'Does globalization affect

\footnotetext{
7 The UNDP Human Development Reports 1995-2009 can be found at. http://hdr.undp.org/en/reports/

8 The UNDP Human Development Reports 1995-2009 can be found at. http://hdr.undp.org/en/reports/

9 The Human Development Index is the geometric mean of the three dimensions mentioned above and can be expressed as HDI $=\left(\mathrm{I}_{\mathrm{Life}}{ }^{1 / 3} \mathrm{I}_{\text {Education }}{ }^{1 / 3} \mathrm{I}_{\text {Income }}{ }^{1 / 3}\right)$. The index can have a value between 0 and 1 . The nearer it is to 1 , the higher the level of human development. For more details about the calculation of the index, http://hdr.undp.org/en/media/HDR 2010 EN TechNotes reprint.pdf

10 The World Bank Database 2010 can be found at http://data.worldbank.org/data-catalog
} 
growth?' (2006). The Index is divided into the sub-indexes: ${ }^{11}$ a) economic globalization, which is characterized by a long distance of flow of goods, capital and services as well as information and perceptions that accompany market exchanges, b) social globalization, which means a spread of ideas, information, images and people; and c) political globalization, which means diffusion of governmental policies.

3. Economic globalization sub-index alone will be used to measure its impact on human development.

4. The three Dreher's sub-indexes (economic globalization sub-index, social globalization sub-index and political globalization sub-index) will be used in the same model to differentiate the effect of each of them on human development.

With respect to the control variables this study uses the State Fragility index measure based on the Polity IV project data set of Marshall and Cole ${ }^{12}$. For the measurement of Delinquency a combination of two variables is used: the dichotomous variable of presence of gangs $^{13}$ in the country, and the homicide rate ${ }^{14}$ reported in each country. Since a high number of homicides are believed to be committed by gangs, the variables were combined in one. For the measurement of Democracy this study uses a dichotomous measure based on the Polity IV data set of Jaggers, Gurr and Marshall (2010) ${ }^{15}$. The measurement of Government Effectiveness is based on the Global Governance Indicators by the World

\footnotetext{
11 "For the calculation, each of the variables is transformed to an index on a scale of one to hundred, where hundred is the maximum value and one is the minimum value. Higher values represent greater globalization. Data are calculated on a yearly basis. The data is transformed according to the percentiles of the original distribution. The weights for the calculation of the sub indices are determined with the help of principal components analysis for the entire sample of countries and years. The weights are then determined in a way that maximizes the variation of the resulting principal component, so that the indices capture the variation as fully as possible. The same procedure is applied to the sub-indices in order to derive the overall index globalization" (Dreher 2006 pp2).

12 "The Fragility Matrix scores each country on both Effectiveness and Legitimacy in four performance dimensions: Security, Political, Economic, and Social. The State Fragility Index, then, combines scores on the eight indicators and ranges from 0 "no fragility" to 25 "extreme fragility." A country's fragility is closely associated with its state capacity to manage conflict; make and implement public policy; and deliver essential services and its systemic resilience in maintaining system coherence, cohesion, and quality of life; responding effectively to challenges and crises, and continuing progressive development". State Fragility Index and Matrix 2010. Global Report 2011, p12. The "State Fragility Index and Matrix. Time-Series Data, 19952009"can be found at http://www.systemicpeace.org/inscrdata.html

${ }^{13}$ In order to verify the existence of gangs in the countries contained in the sample, a variety of news articles and police reports were examined in each country regarding the years 1995-2009.

14 The homicide rate was collected mainly from Wikipedia and also from various police reports of each country and time period contained in the sample.

http://en.wikipedia.org/wiki/List of countries by intentional homicide rate

15 In the database, countries were ranked by subtracting the 10-point autocracy scale from the 10-point democracy scale. Any country that scores at least six points is coded as democratic, and the others as authoritarian. For this research, the variable was dichotomous. That is, whether the country is democratic or not. The measure of democracy used in this research is the "Regime Authority Characteristics and Transitions, 1800-2010"from Polity IV Project, and it can be found at http://www.systemicpeace.org/polity/polity4.htm
} 
Bank (2010) ${ }^{16}$. The index includes Voice and Accountability, Political Stability and Absence of Violence, Government Effectiveness, Regulatory Quality, Rule of Law and Control of Corruption.

The models also take into consideration the fixed effect of each country to highlight the important distinction between analysis of cross-national differences and the analysis of changes within individual countries over time. Country dummies are included in order to correct for factors that might impact a country's human development because most variables vary more across units than over time. Finally, the models also take into account the fixed effects of time. Yearly dummies are used to account for the important differences in national or international influences of shocks that affect the human development in multiple countries at the same time over the course of our time period.

\section{THE MODEL}

In the analysis of these data, a cross sectional time series (CSTS) model is used, estimated through panel-corrected standard errors (PCSE), and country and time dummies to control for fixed effects. This methodological procedure establishes a high threshold for estimating conventional levels of significance. Such estimates are more reliable because the estimation of the standard errors is more efficient and consistent (Beck and Katz, 1996). The use of panel corrected standard errors usually produces conservative results, because it tends to increase the standard errors of the estimates. Furthermore, the inclusion of dummy variables tends to deflate the statistical significance of the other regressors which means that the causal hypotheses might be rejected prematurely, but it also increases our confidence that results which do emerge as significant are not the consequence of unsound statistical assumptions or inappropriate econometric methods (Kaufman et al 2002).

For the analysis of the interaction between human development and globalization, the following empirical model is formulated, where countries are represented by $i$ and time by $t$.

$$
\mathrm{HD}_{i t}=\alpha+\mathrm{Glob}_{i \hbar} \beta_{1}+\mathrm{X}_{i \hbar_{2}} \beta_{2}+\delta_{i k}+\varrho_{t k}+\varepsilon_{i t}
$$

\footnotetext{
16 The availability of the data excludes the years 1995, 1997, 1999 and 2001. In order to correct this, and based on the premise that this kind of indicators do not vary considerably from one year to another, the data was duplicated so that the blanks could be filled. For example, the data corresponding to the year 1996 was duplicated for 1995, year 1998 was duplicated for 1997, and year 2000 was duplicated for 1999 and 2002 was duplicated for 2001.The Worldwide Governance Indicators from the World Bank, 2010 can be found at http://info.worldbank.org/governance/wgi/index.asp
} 
In equation (1), $\mathrm{HD}_{i t}$ represents the human development in country $i$ during year $t$. Glob is a vector for different proxies of globalization such as Trade and FDI (measurement 1), Economic Globalization (measurement 2), Economic, Social and Political Globalization (measurement 3), and the overall Globalization index (measurement 4). $\mathrm{X}$ is a vector that includes the independent variables presented above, which either are considered as potential mediators through which globalization influences human development or as exogenous factors affecting human development, but not themselves influenced by globalization. $\delta_{i k}$ corresponds to a set of country (dummies) fixed effect $(\mathrm{k}=$ $1,2,3 \ldots$ 16) that captures stable differences in human development between countries. Argentina is dropped by the software because of perfect collinearity in the regression model. $\varrho_{t k}$ is a set of period (dummies) fixed effect $(\mathrm{k}=1,2,3, \ldots 14)$ capturing the influence of shocks that affect human development in multiple countries at the same time. Year 1995 is dropped by the software because of perfect collinearity in the regression model. $\varepsilon_{i t}$ is an error term assumed to be normally distributed.

Our dependent variables are a) Human Development overall index, b) Long and healthy life (measured by life expectancy at birth), c) knowledge (measured by public spending on education), and d) a decent standard of life (measured by the GDP per capita). For each of the dependent variables, the four measures of globalization are applied in order to determine the difference of the impact on each of the human development variables, if existent.

\section{RESULTS}

For the presentation of the results, two tables were constructed. Table 1 shows the regression results of the four estimation models on the four dependent variables considering the influence of several controls without the country and time dummies, while the table 2 shows the same results with the country and time dummies ${ }^{17}$. In table 1 , the results of the estimation of the relationship between human development and globalization show that several proxies for globalization indicate different effects on the human development in Central and South American countries. This agrees with general hypothesis 1: for the overall human development index, we have FDI with strong positive impacts, while trade has strong negative impacts, presumably because in the case of developing

${ }^{17}$ The country and time dummies were not shown on table 2 due to space. However, the result of the country and time dummies are explained among the general explanation of the results. 
countries FDI permits the creation of new employments through investment, while trade puts developing countries in a serious disadvantage compared to the industrialized countries.

The overall globalization index has strong positive impacts, constantly. We can also see from the results that the economic globalization sub-index has negative impacts on human development. And when the economic, social and political globalization, are tested together, economic globalization has strong negative impacts, while both social and political globalization have strong positive impacts. These results mostly agree with the general hypotheses. Remarkably, a country's participation in the international political system can bring many good things such as management of epidemic diseases, human rights issues or global environmental concerns (Ming-Chang 2006). With respect to the controls, state fragility index has strong negative impacts in the four models. Delinquency, as expected, has strong negative impacts on human development constantly in the four models. Democracy shows positive effects but not significant on human development. Finally, the government effectiveness shows strong positive effects constantly in the four models used for the estimations.

In table 2, we can see the results of the estimations for the relationship between human development and globalization with country and time dummies. We have that all the measurements of globalization have positive but not significant impacts. The control variables show no strong impact on the four models used for the estimations. However, democracy and government effectiveness became negative. In order to understand this, we should take into consideration that, as explained before, the inclusion of dummies tends to deflate the statistical significance of the other regressor (Kaufman et al 2002). Regarding the country dummies, as expected all the countries showed a negative impact when compared to Argentina, which is the omitted variable and the highest HDI of the region. Costa Rica, Chile and Uruguay show a negative sign but not significant. Those countries are situated among the highest HDI in the region. With respect to the time dummies, almost all the years showed strong negative impacts when compared to 1995 which is the omitted variable, except 2009 which showed strong positive impacts.

A Decent Standard of Life (Measured by GDP per capita): In table 1, we find that FDI has strong positive impacts while Trade has strong negative impacts on the GDP, consistently. The economic globalization sub index shows negative impacts. The overall globalization index shows strong positive impacts, constantly. Finally, when the three sub- 
indexes are tested together, social and political globalization showed strong positive impacts, while economic globalization showed negative impacts. In fact, when the three sub-indexes are the only independent variables, the three of them show positive impacts, but when delinquency is added, economic globalization becomes negative, and when state fragility index is added, it becomes even more negative. This mostly agrees with the specific hypotheses.

State fragility index and delinquency show strong negative impacts in the four models. And surprisingly, democracy shows negative impacts in GDP per capita in three of the four models. Finally, government effectiveness shows positive impacts on GDP per capita. When compared to table 2, FDI and trade both showed strong negative impacts on GDP. The economic globalization showed positive impacts. The overall globalization index showed negative impacts. And when the three sub-indexes are tested together, economic and social globalization showed positive effects, while political globalization showed strong negative impacts on GDP per capita. The control variables showed a very curious behavior. Surprisingly, state fragility index showed positive impacts, as well as delinquency, while democracy (models 3 and 4) and government effectiveness showed negative impacts, possibly as a result of the inclusion of the dummies in the model.

A Long and Healthy Life (Measured by Life Expectancy at Birth): In table 1 we continue to see the same pattern. While FDI shows strong positive effects, trade shows strong negative effects on life expectancy. The overall globalization index shows strong positive effects while the economic globalization sub index shows negative not significant effects. When the three sub-indexes are tested together, economic globalization shows negative while social and political globalization show strong positive effects on life expectancy. This agrees mostly with the specific hypotheses. Control variables show the expected result. State fragility index and delinquency show strong negative impacts. Democracy shows positive impacts but government effectiveness shows negative impacts in the four models.

When compared to table 2, FDI shows positive impacts while trade shows negative impacts, neither of them significant. The overall globalization index shows strong positive effects. Economic globalization sub index shows positive and when the three sub-indexes are tested together, all of them show positive impacts on life expectancy. With respect to the controls, Fragility index, government effectiveness, and delinquency show negative effects. Democracy shows positive effects on life expectancy. 
Education (Measured by Public Spending on Education): in Table 1, all the measurements of globalization in models (1), (2) and (3) showed positive impacts. However, in model (4) when the three sub-indexes were tested together, economic globalization showed strong positive impacts while social and political globalization showed strong negative impacts on public spending on education. Regarding the control variables, state fragility showed the expected negative effects in the four models. The other three variables showed an interesting behavior. Delinquency showed strong positive effects in the four models. The explanation might be that when delinquency and insecurity are high, education seems to be the logical path to follow in order to reduce them and attract foreign and national investment. Democracy and government effectiveness showed negative effects in the four models. When compared to Table 2, all measurements of globalization showed positive effects in models (1) and (2). Economic globalization subindex showed negative impacts and when the three sub-indexes were tested together social and political globalization showed negative effects while economic globalization showed positive effects on public spending on education. All the control variables show the same sign as in table 1.

\section{CONCLUSION}

So can we conclude that globalization is positive or negative for developing countries? The preceding analysis has demonstrated that globalization can have diverse impacts on human development of Central and South American countries. However, these diverse effects depend in the first place on how the concepts of globalization and human development themselves are measured and we can also notice the same pattern when human development is disaggregated. In the second place, the results of the test also depend on the level of state fragility and delinquency. That is, the impact of globalization on the human development varies at different levels of state fragility and delinquency. So we can imply that in general, the globalization process is likely to bring negative results to those countries with high levels of state fragility and delinquency. As states work on the strengthening of their institutions and democracy, as well as in the reduction of a violent environment, the effects of globalization promise to be positive on the human development. 
From the perspective of an industrialized country, there is no doubt that globalization is definitely a positive process that has many more advantages than disadvantages. From the perspective of a developing country, it is clear that openness to economic globalization will not automatically lead to human development. The opportunities offered by globalization will be successfully seized depending on the integration of economic, social and political globalization policies together working in favor of the nation rather than in favor of the great capitals. And of course the strengthening of the government is required, as well as the correct functioning of democracy, and the reduction of delinquency and insecurity in order to promote national and foreign investments. 
TABLE 1. DETERMINANTS OF HUMAN DEVELOPMENT AND ITS INDICATORS IN 17 CENTRAL AND SOUTH AMERICAN COUNTRIES, 1995-2009

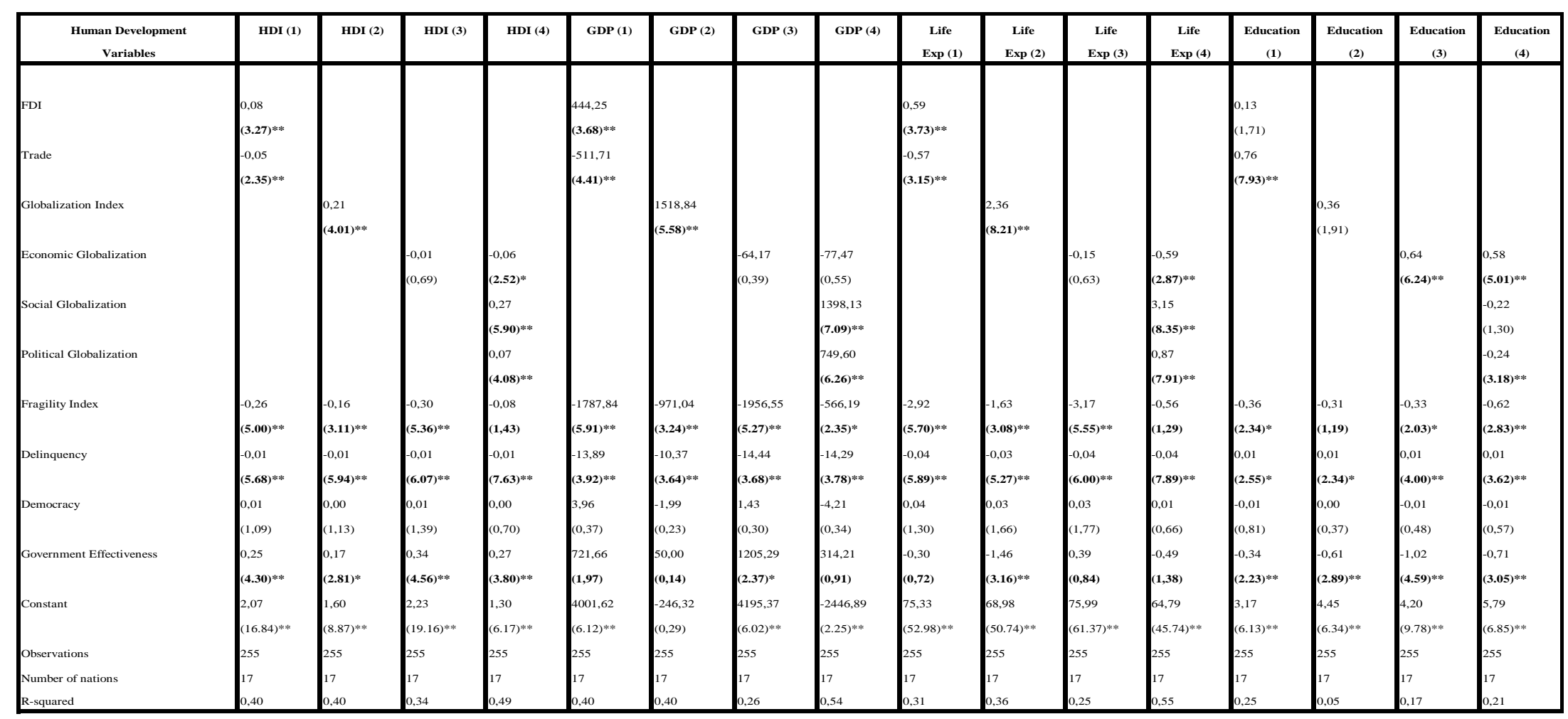

$*$ significant at $5 \%$; ** significant at $1 \%$ 
TABLE 2. DETERMINANTS OF HUMAN DEVELOPMENT AND ITS INDICATORS IN 17 CENTRAL AND SOUTH AMERICAN COUNTRIES, 1995-2009 (WITH TIME AND COUNTRY DUMMIES)

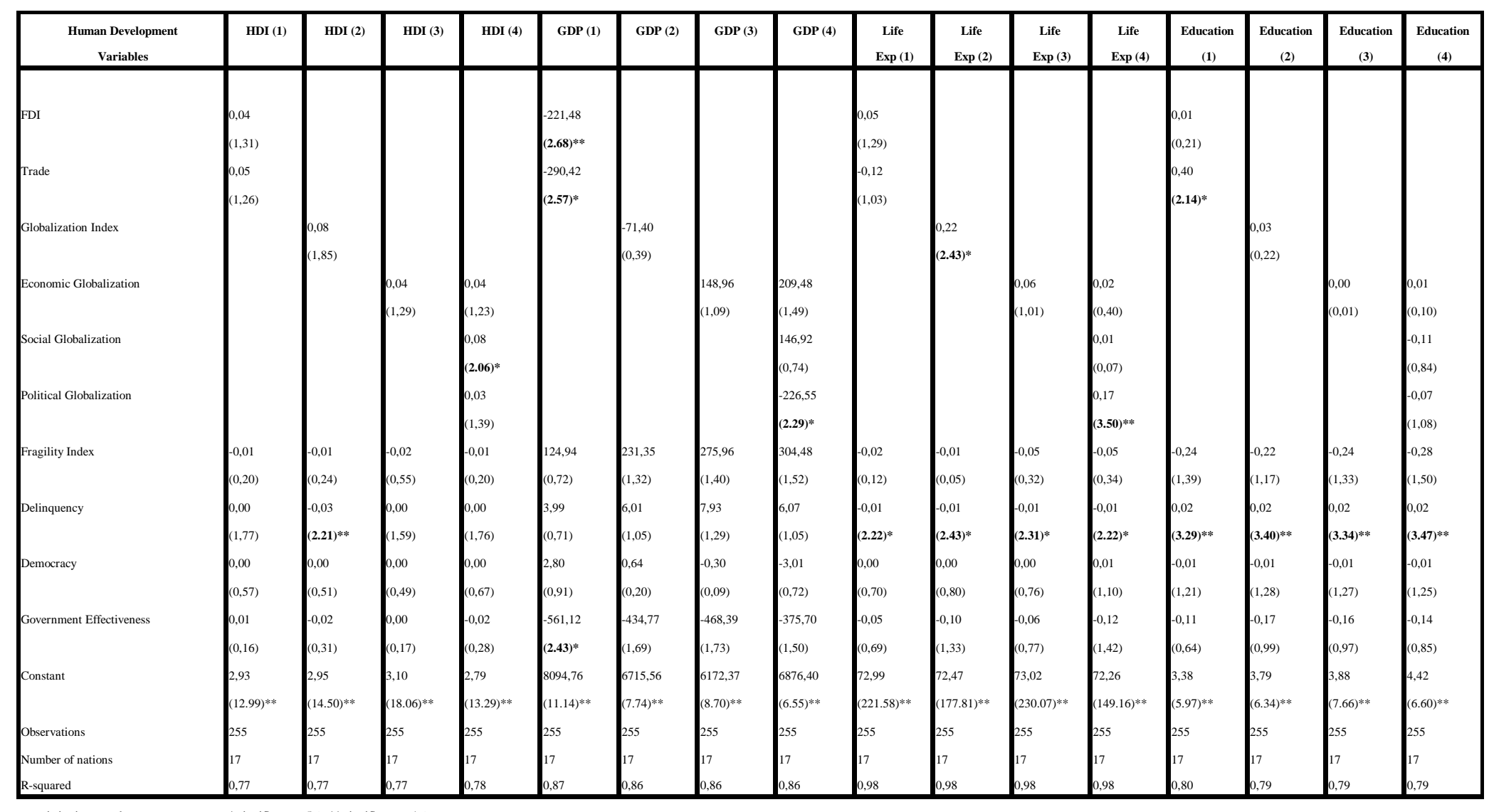




\section{REFERENCES}

DREHER, A. (2006): "Does Globalization Affect Growth? Evidence from a new Index of Globalization", Applied Economics Vol 8 (10): pp 1091-1110.

BAYLIS, J, S.; Smith and P. Owens. (2008). "The Globalization of World Politics." Oxford University Press

BEER, L. and T. Boswell (2001). "The Effects of Globalization on Inequality: A CrossNational Analysis." Halle Institut Occasional Paper. Department of Sociology. Emory University

BECK, N.; and J. Katz. (1996). "Nuisance vs. Substance: Specifying and Estimating TimeSeries-Cross-Section Models". Political Analysis Vol 6 (1) pp 1-36

BURTON, J. (1972). "World Society.” Cambridge: Cambridge University Press

COOPER, R. (1968). “The Economics of Interdependence.” New York: McGraw-Hill.

DREHER, A. (2006). "Does Globalization Affect Growth? Evidence from a New Index of Globalization." Applied Economics Vol 38 (10) pp 1091-1110

ELLWOOD, W. (2001). “The Neo-Nonsense Guide to Globalization.” London, Verso.

GRENNES, T. (2003). “Creative Destruction and Globalization.” Cato Journal. Vol 22: pp 543-558

KAUFMAN, R; Segura-Ubiergo, A.; Nelson, J.; and C. Bradford (2002). "Globalization, Domestic Politics and Social Spending in Latin America". Latin American Program. Woodrow Wilson International Center for Scholars.

LI, Q. and R. Reuveny (2003). "Economic Globalization and Democracy: An Empirical Analysis.” British Journal of Political Science, forthcoming

LUCAS, R.E. (1988): "On the Mechanics of Economic Development." Journal of Monetary Economics Vol 22: pp 3-42

MARSHALL, M. G. and Cole, and R. Benjamin (2011) "State Fragility Index and Matrix 2010". Global Report 2011, p12. The "State Fragility Index and Matrix. Time-Series Data, 1995-2009” Available at http://www.systemicpeace.org/inscr/inscr.htm. Last access August 4, 2014.

MAYER-FOULKES, D. (2006). "Globalization and the Human Development Trap." CIDE Mexico

MCLUHAN, M. (1964). “Understanding Media.” London: Routledge

MING-CHANG, T. (2006). "Does Political Democracy Enhance Human Development in Developing Countries? A Cross-National Analysis." The American Journal of Economics and Sociology. Vol 65 (2), pp 233-268 
MODELSKY, G. (1972). "Principles of World Politics.” New York: Free Press

MORSE, E. (1976). "Modernization and the Transformation of International Relations." New York: Free Press

OTTAWAY, M. and S. Mair. (2004). "States at Risk and Failed States: Putting Security First.” Policy Outlook. Carnegie endowment for International Peace

PETRAS, J. and H. Veltmeyer. (2001). “Globalization Unmasked.” Zed, London

SIRGY, M.J., D.J. Lee, C. Miller and J.E. Littlefield. (2004).’'The Impact of Globalization on a Country's Quality of Life: Toward an Integrated Model." Social Indicators Research, Vol 68: pp 251-298

SMART, B. (2003). "Economy, Culture and Society: A Sociological Critique of Neo-liberalism." Open University Press, Buckingham

SORENSEN, Georg. (2000). "Sovereignty, Security and State Failure". Paper presented at the conference Globalization and the Failed State, Florence, Italy, 2000.

UNDP. United Nations Development Programme. (1992). "Human Development Report, 1992. Global Dimensions of Human Development.” New York: Oxford University Press

UNDP. United Nations Development Programme. (1999). "Human Development Report, 1999. Globalization with a Human Face.”New York: Oxford University Press

UNDP. United Nations Development Programme. (2000). "Human Development Report, 2000. Human Rights and Human Development” New York: Oxford University Press

UNDP Report - Belize 2011. Available at. http://www.undp.org.bz/humandevelopment/what-is-human-development/ Last access August 4, 2014. 